\title{
Hydraulic Stability of Fly Ash-Bentonite Mixtures in Landfill Containment System
}

\author{
Mochamad Arief Budihardjo1*, Syafrudin Syafrudin', Ika Bagus Priyambada1, \\ Bimastyaji Surya Ramadan ${ }^{1}$ \\ 1 Department of Environmental Engineering, Faculty of Engineering, Universitas Diponegoro, J. Prof. H. \\ Sudarto, SH Tembalang, Semarang, 50275, Indonesia \\ * Corresponding author's e-mail: m.budihardjo@ft.undip.ac.id
}

\begin{abstract}
This study aimed to examine the performance of fly ash mixed materials with bentonite binder (FAB) as a recent low-cost containment system to withstand leachate infiltration. The mixture of fly ash with clay (bentonite) can increase the strength of stability and strengthen cohesion bonds between molecules. Direct shear, falling head, Atterberg limit and specific gravity test have been conducted as a preliminary study to determine the precise mixture composition of fly ash-bentonite (FAB) landfill liners. Some bentonite composition: $0 \%\left(\mathrm{FAB}_{0}\right), 15 \%$ $\left(\mathrm{FAB}_{15}\right), 20 \%\left(\mathrm{FAB}_{20}\right), 25 \%\left(\mathrm{FAB}_{25}\right)$ and $25 \%$ - cured with $\mathrm{NH}_{4} \mathrm{Cl}\left(\mathrm{FAB}_{25 \mathrm{~s}}\right)$ for 24 hours, which mixed with fly ash, showed the value of shear stability at normal stress reaching $9.5 \mathrm{kNm}^{-2}, 15.48 \mathrm{kNm}^{-2}, 45.06 \mathrm{kNm}^{-2}, 46.26 \mathrm{kNm}^{-2}$ and $13.67 \mathrm{kNm}^{-2}$, respectively. It showed that the greater the content of bentonite in the mixture, the higher the shear stress produced. Curing with saline solution can reduce the shear stress of the FAB mixture. The safety test results using Geoslope $/ \mathrm{W}^{\circledR}$ show that the addition of bentonite will increase bonding between particles, bearing capacity, and shear strength of the material. The largest safety factor of 1.674 obtained from FAB20 material meets the safety standard for short-term slope stability. The use of fly ash material with bentonite is expected to be an alternative landfill liner material.
\end{abstract}

Keywords: stabilization, containment system, bentonite, fly ash, permeability

\section{INTRODUCTION}

Liner system is a semi-permeable layer that functions to prevent the occurrence of pollutant diffusion and resist leachate infiltration into the soil (Alla et al., 2017). Landfill waterproof layers generally consist of the materials that have low permeability to minimize pollutant infiltration (Mukri et al., 2018). Various types of minerals are often used as a waterproof liner model because of the low permeability coefficient, including bentonite (Ruiz et al., 2012), kaolinite (Vimonses et al., 2009), and montmorillonite (Çoruh and Ergun, 2010). Although bentonite has advantages in the low potential of pollutant infiltration, bentonite has a shear stability that is not too strong, so it has the potential to collapse when used in slope areas (Bergado et al., 2006).
In general, stabilization of leachate-retaining soils can be done mechanically and chemically. In principle, mechanical soil stabilization is done by increasing strength and carrying capacity to the existing soil by regulating the gradation of the relevant soil grain and increasing its density. Adding and mixing local soil (natural soil) with other types of soil can be applied to obtain a new and better gradation (Turan and Ergun, 2009). Critical factors in the use of mechanical soil stabilization methods are the level of soil gradation that has binding capacity (composite material) and water content (Lin et al., 2018). The method for improving soil properties is also very dependent on the duration of curing because the chemical processes that occur in the course of improving soil properties require time to react (Sivapullaiah and Baig, 2011). The base layer of the landfill must 
have sufficient stability to avoid any degradation or cracking that might occur.

The efforts to improve the stability of waterproof soil leachate retaining substrate by using waste materials have actually been widely studied. Kalkan (2006) as well as Coruh and Ergun (2010), for example, used red mud produced from the bauxite industry to increase hydraulic conductivity, unconfined compressive strength and vertical swelling percentage values (Çoruh and Ergun, 2010; Kalkan, 2006). The use of mining waste for landfill liners was also investigated by Maritsa (2016) who used spilitic sand recovered from ferronickel mining. The addition of $3.0 \mathrm{wt} \%$ bentonite can reduce the permeability coefficient to less than $10^{-9} \mathrm{~m} / \mathrm{s}$ which - if spilitic sand is used alone - has a hydraulic conductivity value of $3.6510^{-6} \mathrm{~m} / \mathrm{s}$. The use of fiber (Ehrlich et al., 2019), rubber (Cokca and Yilmaz, 2004) and tire chips (Mukherjee and Mishra, 2017) may be able to reduce the occurrence of cracks and increase hydraulic conductivity. In addition, several other waste materials such as fly ash (Alla et al., 2017; Çoruh and Ergun, 2010; Mishra and Ravindra, 2015; Sivapullaiah and Baig, 2011), cementitious materials (Ganjian et al., 2004), sewage sludge (Herrmann et al., 2009), paper pulp sludge (Slim et al., 2016), and coal gangue (Wu et al., 2017) also has been proven to be used effectively as a base coating for landfills. The purpose of adding/mixing waste materials with local soil is to strengthen the stability of the subgrade, especially when there is a static or dynamic load that is capable of disrupting the stability of the subgrade. In addition, the cost of stabilizing waste materials (commonly categorized as hazardous materials) can be reduced due to the value of the benefits of using by-product material as a base coating for landfills (Kalkan, 2006).

The use of fly ash as a base coating for landfill has been extensively studied by researchers. Leachability test of trace elements using fly ash have been carried out by Sivapullaiah and Baig (2011) under various conditions of $\mathrm{pH}$, addition of gypsum and lime and Çoruh and Ergun (2010) by comparing the performance of phosphogypsum, fly ash and red mud as a leachate barrier (Çoruh and Ergun, 2010; Sivapullaiah and Baig, 2011). Mishra and Ravindra (2015) as well as Alia et al. (2017), studied the characteristics of fly ash as a base coating for landfill by testing the level of compressibility, hydraulic conductivity, and volumetric shrinkage of a mixture of fly ash with local soil (Alla et al., 2017; Mishra and Ravindra, 2015). Fly ash is a very fine material with very uniform gradations derived from the combustion of biomass (Çoruh and Ergun, 2010). Fly ash includes the materials referred to as pozzolanic, because they contain pozzolanic materials such as silica $\left(\mathrm{SiO}_{2}\right)$, iron oxide $\left(\mathrm{Fe}_{2} \mathrm{O}_{3}\right)$, aluminum oxide $\left(\mathrm{Al}_{2} \mathrm{O}_{3}\right)$, calcium oxide $(\mathrm{CaO})$, magnesium oxide $(\mathrm{MgO})$, and sulfate $\left(\mathrm{SO}_{4}\right)$ (Sivapullaiah and Baig, 2011). However, the evaluation of the mechanical stability of soil that uses fly ash as a base coating for landfill has not been found yet. The addition of fly ash in expansive soils is intended to form a pozzolanic reaction, which is the reaction between the calcium contained in fly ash with alumina and silicate in soil. This chemical compound has self-cementing properties (the ability to harden and increase strength when reacting with water), so it can increase the stability of shear soil (Slim et al., 2016). To date, the shear tests that consider forcing failure have only been found in the studies of Lin et al. (2018) who studied the behavior of GCL shear strength on composite liners. The exact value of mixtures between bentonite as the main mineral in local soil and fly ash is very important to know, because it will affect the optimum shear strength and permeability. In addition, the selection of the right composition can prevent the occurrence of landslides in landfills (Lin et al., 2018). This study aimed to analyze the shear strength and optimize the addition of bentonite and ripening to the shear strength and the value of fly ash permeability as a waterproof soil for leachate retaining.

\section{METHODOLOGY}

\section{Materials preparation}

Bentonite clay was obtained from the Giriwoyo sub-district, Wonogiri district, Central Java, in the form of fine powder bentonite materials that passed $0.075 \mathrm{~mm}$ mesh filter with specific gravity of $2.75,43 \%$ optimum moisture content and $>$ $75 \%$ smectite content. Therefore, the fly ash used as the main material in this study was taken from one of the steam power plants in Indonesia. The fly ash used is classified as a Class F fly ash, containing less than $10 \% \mathrm{CaO}$, which is the result of burning anthracite or coal bitumen. Other compounds contained in the fly ash typically include: $\mathrm{SiO}_{2}(30-50 \%), \mathrm{Al}_{2} \mathrm{O}_{3}(45-60 \%), \mathrm{MgO}, \mathrm{K}_{2} \mathrm{O}$ and 
a little $\mathrm{Na}_{2} \mathrm{O}$. Before using it, fly ash was activated using an alkaline solution for 60 minutes and heated at $90^{\circ} \mathrm{C}$. Then, it was washed with distilled water until the neutral $\mathrm{pH}$ returned. Then, the fly ash was reheated at $140^{\circ} \mathrm{C}$ for 1 hour and dried at room temperature. Fly ash cannot be settled because of the small $\mathrm{CaO}$ content.

Various variations of fly ash and bentonite mixes of $0 \%$ (FAB0), 15\% (FAB15), 20\% (FAB20) and 25\% (FAB25) were hydrated for 24 hours with distilled water and one mixture of FAB was hydrated in a salt solution $\left(\mathrm{NH}_{4} \mathrm{Cl} 1 \mathrm{~N}\right)$ with a concentration of $7.1 \mathrm{gL}-1\left(\mathrm{FAB}_{25 \mathrm{~s}}\right)$. The amount of concentration was obtained from the characteristics of the Jatibarang Landfill salinity which is the main landfill in Semarang City, Indonesia. The variation of bentonite used in this study is in line with the research conducted by Pandey and Jain (2017) which stated that the use of bentonite by $20 \%$ has a permeability coefficient of $0.9 \times 10-7 \mathrm{~cm} \cdot \mathrm{s}^{-1}$ (Pandey and Jain, 2017). Inorganic salts, which were used to hydrate bentonite liners, are known to reduce swelling volume, liquid limit, compression index, increase hydraulic conductivity (Budihardjo, 2016; Shariatmadari et al., 2011) and increase the desiccation cracking in the vertical liner. Cracking increases the value of bentonite permeability in the liner system. In addition, alkaline pore water can cause bentonite dissolution, thereby reducing the swelling capacity of bentonite (Xu et al., 2018). Therefore, the impact of the presence of liner hydration on salt solutions was considered in this study.

\section{Experimental procedures}

A preliminary test was conducted by using Proctor Standart Test, Atterberg Limit Test, and Material Composition Test. Direct shear and permeability (using falling head methods) tests were also conducted to determine the optimum mixtures of fly ash - bentonite (FAB) liner. Proctor Standard Tests were carried out using gravimetric techniques to determine the relationship between the optimum moisture content (OMC) and soil density of each mixture. At the next stage, the Atterberg limit test was used to determine the liquid limit of the plastic limit and specific gravity. Liquid limit is the boundary between the soil with a liquid state and a plastic state. This situation is determined by the Casagrande device (ASTM D-4318), where - at a certain moisture content - a scratch of $12.5 \mathrm{~mm}$ in the center of the test specimen closes at 25 beats. Plastic limit is the boundary between the soil in plastic and semiplastic states. This situation can be achieved if a soil with a certain water content can be formed into a roll of soil with a diameter of $3.18 \mathrm{~mm}$ having a little cracking on the outside (ASTM D-4318). Plasticity index is calculated from the difference between plastic and liquid limit. Scanning electron microscope - energy-dispersive $\mathrm{X}$-ray spectroscopy (SEM-EDX) used in this study is a composition test method to determine the morphology of the sample being tested.

Soil shear strength is the internal resistance of the soil per unit area to collapse or shift along the shear area in the soil. The soil shear strength is defined in the effective stress of the soil. The value of shear strength can be obtained by the equation found by Mohr-Coulomb presented in equation (1).

$$
\tau=c^{\prime}+\sigma^{\prime} \tan \phi ’
$$

where: $s$ is the shear strength of the soil, $c^{\prime}$ represents soil cohesion, $\sigma^{\prime}$ is the effective soil stress in the shear plane,

$\phi^{\prime}$ is the inner shear angle.

The values of c' and ' ${ }^{\prime}$ ' of a soil can be obtained from laboratory testing, one of which uses direct shear test.

Direct shear test is a test used for sandy soil consisting of a metal box containing a sample of a square or circular section. The box is divided into two equal sides in a horizontal direction having a height of 1 inch $(25.4 \mathrm{~mm})$. The standard to carry out this test is ASTM D3080, where the test sample is inserted into an inspection ring that has been locked into one. Then, the sample is given a load evenly and saturated for 24 hours. The shift reaction will be read to obtain triplicate dial reading with the same value. Then, the sample is replaced by repeating the steps above with different normal loads. Shear stress and normal stress values are obtained from formulas (2) and (3).

$$
\begin{aligned}
& \text { Shear stress }=\tau_{\mathrm{s}}=\frac{\text { Dial Reading }}{\text { Area }} \\
& \text { Normal stress }=\tau_{\mathrm{n}}=\frac{\text { Total Load }}{\text { Area }}
\end{aligned}
$$


This test was carried out to determine the parameters of soil shear strength (s), cohesion (c) and soil shear angle $(\varnothing)$. This test method also determined the value of the permeability coefficient $(\mathrm{K})$, which states the ease of flow of water through the sample soil. The data was analyzed by using Excel $^{\circledR}$ and Geo slope/W software from Geostudio.

\section{RESULTS AND DISCUSSION}

\section{Proctor standard test}

The consistency of clay and other cohesive soils is strongly influenced by the water content. Plasticity index and liquid limit can be used to determine the characteristics of expansion. Standard Proctor Test was used to determine the optimum moisture content (OMC) and maximum dry density (MDD) values of the five variations of the fly ash and bentonite composites (Kalkan, 2006). Figure 1 shows the comparison of MDD and $\mathrm{OMC}$ on pure fly ash $\left(\mathrm{FAB}_{0}\right)$. These values indicate that the MDD value varies with a value of $1.48 \mathrm{gr.cm}^{-3}-1.93$ gr.cm ${ }^{-3}$ and $\mathrm{OMC}$ with a value of $4 \%-22 \%$. On the basis of Figure 1, the maximum dry density is $1.94 \mathrm{gr} / \mathrm{cm}^{3}$ and the optimum moisture content from the use of fly ash material is $11.25 \%$. The value of OMC (\%)/MDD $\left(\mathrm{gr}^{\mathrm{cm}} \mathrm{cm}^{-3}\right)$ in this study is approximately the same as varamin clay in the study of Shariatmadari et al. (2011) which is equal to $14 / 1.86$. Nevertheless, the OMC value is still lower than the study conducted by which the fly ash used has a value of $23.8-24.0 \%$ (Sivapullaiah and Baig, 2011)

According to Rout and Singh (2017), the addition of bentonite can increase the OMC value until the bentonite content reaches its optimum value. The OMC value will increase along with the clay content in the mixture. It is because of the high specific surface area and adsorption capacity that can trap water in pores of the clay. However, improper addition of bentonite can also reduce the OMC value because when fine particles (bentonite) are added to fly ash mixtures, fine particles will be trapped in the intra-particle cavity, which can reduce the available space for water in the intra-particle cavity (Rout and Singh, 2017). When the liner mixtures are hydrated with a saline solution (especially with salts that have a greater cation valence), there is the potential for an increase in dry density and a decrease in the optimum water content. It is because of the decrease in the thickness of the diffuse double layer which is then able to reduce the bond of water with bentonite/ fly ash material (Shariatmadari et al., 2011). Fly ash is known to have the characteristics of fine material which has more specific surface area compared to local soil, so it requires greater water content when compacted with local soil.

\section{Atterberg Limit Test}

Table 1 represents liquid limit, plastic limit, plasticity index and specific gravity of each treatment. The greatest increase in liquid limit value from $0 \%$ to $35 \%$ was seen after the addition of

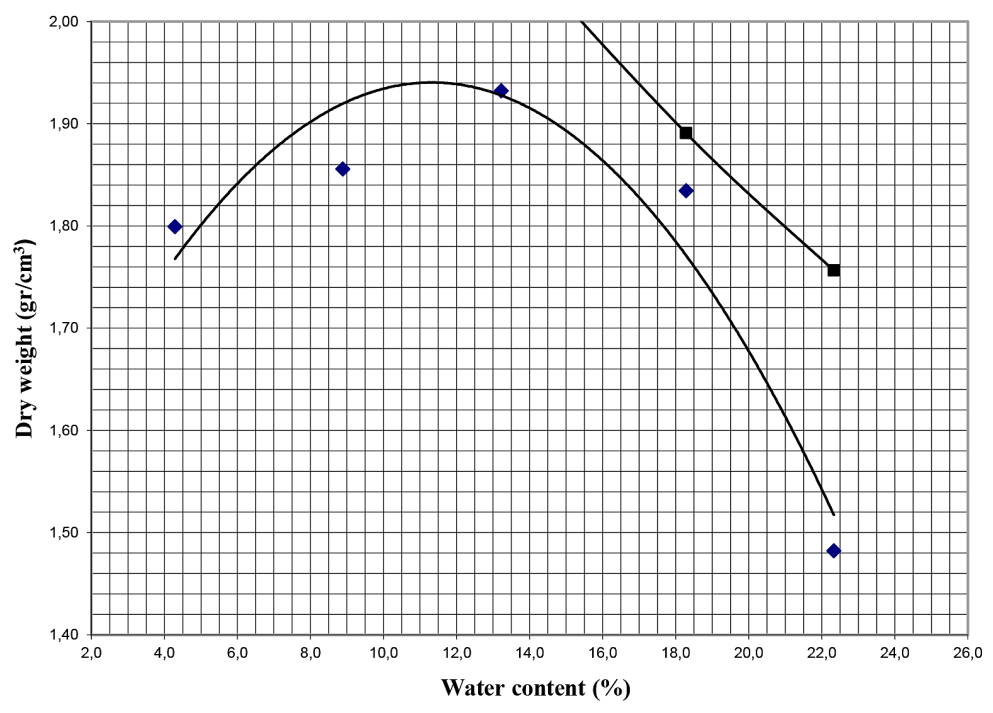

Figure 1. Proctor standard test result graph 
bentonite was carried out in as much as $15 \%$ of the amount of pure fly ash. The same conditions occur in the plastic limit and plasticity index. This increase in soil plastic index occurs because water can bind bentonite and fly ash so that the plasticity increases and the volume of soil grains becomes greater due to the clotting reaction. The more bentonite is added to the mixture, the plastic index value will increase greater.

High plasticity occurs due to the changes in the soil system with water, which results in disruption of the balance of forces in the soil structure. The tensile forces acting on adjacent particles consist of electrostatic forces that depend on the mineral composition and the distance between the surface of the particles. Sivapullaiah and Baig (2011) stated that the fly ash that is not mixed with bentonite or other materials is classified as non-plastic material. This finding is in line with the results shown in this study where the $\mathrm{FAB}_{0}$ plasticity index value is 0 . According to Benson et al. (1992) the use of composites material for landfill liners must have a hydraulic conductivity $\leq 1 \times 10^{-7} \mathrm{~cm} \cdot \mathrm{s}^{-1}$, plasticity index $\geq 7 \%$, and liquid limit $\geq 20 \%$ (Benson et al., 1994). Alla and her research team (2017) have proven that the addition of bentonite by $15 \%$ of the total weight of fly ash is known to effectively reduce hydraulic conductivity and increase the plasticity index to above the standards stated by Benson et al. (1992). In contrast to this study, the addition of $15 \%$ bentonite turned out to only produce a plasticity index of $6 \%$ (the value is very far from the results of the study of Alla et al., who were able to achieve a PI value of $30 \%$ ) so that it still needs more bentonite additions to make it feasible as a landfill containment system (Alla et al., 2017).

\section{Material Composition}

The morphology and composition of the material contained in the fly ash - bentonite sample was evaluated using the SEM-EDX test method. On the basis of the SEM-EDX test results that have been carried out on fly ash samples, fly ash morphologically consists of solid particles that are spherical in shape, and most are in the form of hollow round particles. Fly ash constituent particles are granules with varying sizes, ranging from 1-5 $\mu \mathrm{m}$. Fly ash consists of the particles that have spherical shape. Fly ash has a large hydraulic conductivity value due to its nature as a non-plastic material. When fly ash is mixed with other additives, the compressibility will be reduced. However, the cause of the decrease in hydraulic conductivity is not yet fully understood (Sivapullaiah and Baig, 2011). In the SEM-EDX test results, the bentonite particles coagulate and form groups in layers. This is because bentonite has a complex aluminum silicate compound with a basic unit of tetrahedral silica and octahedral aluminum that forms silica sheets and octahedral sheets. Thus, in a mixture of fly ash and bentonite, the two compounds overlap in filling the gaps between particles. The gap between samples is occupied by both types of binders. Bentonite particles with different sizes of pores are occupied by fly ash particles of different sizes. Furthermore, a gap between fly ash grains is occupied by bentonite and the gap contained in bentonite is occupied by fly ash particles or vice versa. This condition leads to the formation of a dense structure with low permeability (Pandey and Jain, 2017).

Some of the constituent elements possessed by a mixture of fly ash and bentonite (FAB)

Table 1. Different response of treatment

\begin{tabular}{|c|c|c|c|c|c|}
\hline No. & Treatment & Liquid limit (\%) & Plastic limit (\%) & Plasticity index (\%) & Specific gravity $\left(\mathrm{g} / \mathrm{cm}^{3}\right)$ \\
\hline 1 & $\mathrm{FAB}_{0}$ & 0 & 0 & 0 & 2.897 \\
\hline 2 & $\mathrm{FAB}_{15}$ & 25 & 19 & 6 & 2.188 \\
\hline 3 & $\mathrm{FAB}_{20}$ & 28 & 20 & 8 & 2.680 \\
\hline 4 & $\mathrm{FAB}_{25}$ & 35 & 23 & 12 & 2.398 \\
\hline
\end{tabular}

Table 2. SEM EDX test results

\begin{tabular}{|l|c|c|c|c|c|c|c|c|c|c|c|}
\hline \multicolumn{1}{|c|}{ Element } & $\mathrm{C}$ & $\mathrm{O}$ & $\mathrm{Na}$ & $\mathrm{Mg}$ & $\mathrm{Al}$ & $\mathrm{Si}$ & $\mathrm{S}$ & $\mathrm{K}$ & $\mathrm{Ca}$ & $\mathrm{Ti}$ & $\mathrm{Fe}$ \\
\hline Mass (\%) & 9.39 & 52.34 & 1.23 & 2.56 & 7.35 & 14.34 & 0.53 & 1.08 & 4.41 & 0.47 & 6.31 \\
\hline Oxide & $\mathrm{Na}_{2} \mathrm{O}$ & $\mathrm{MgO}$ & $\mathrm{Al}_{2} \mathrm{O}_{3}$ & $\mathrm{SiO}_{2}$ & $\mathrm{SO}_{3}$ & $\mathrm{~K}_{2} \mathrm{O}$ & $\mathrm{CaO}$ & $\mathrm{TiO}_{2}$ & $\mathrm{FeO}$ & & \\
\hline Mass (\%) & 1.97 & 5.13 & 17.16 & 39.08 & 1.72 & 1.68 & 7.94 & 1.00 & 10.33 & & \\
\hline
\end{tabular}



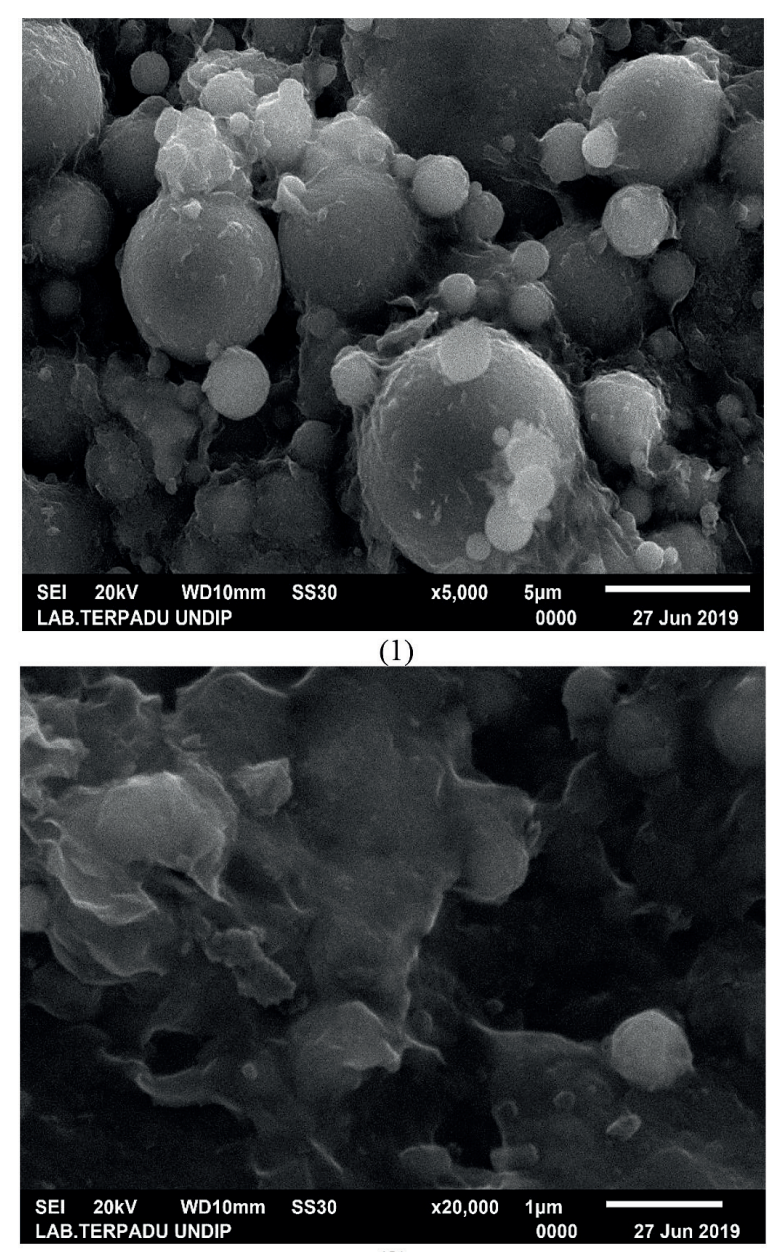

(2)

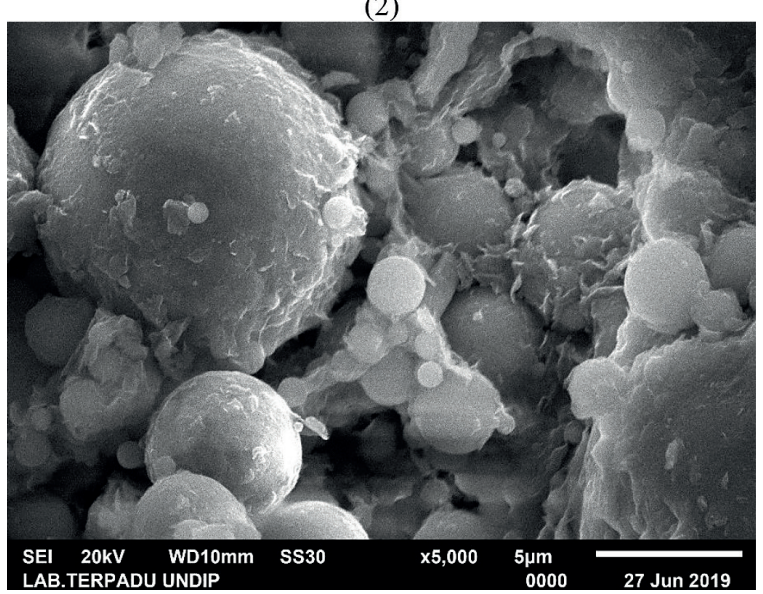

Figure 2. SEM Image of (1) Fly Ash in 5,000x magnification, (2) Bentonite in 20,000x magnification, (3) Fly Ash - Bentonite

(FAB) 5,000x magnification

include $\mathrm{C}, \mathrm{O}, \mathrm{Na}, \mathrm{Mg}, \mathrm{Al}, \mathrm{Si}, \mathrm{S}, \mathrm{K}, \mathrm{Ca}$, Ti and $\mathrm{Fe}$. The lowest concentration value is $\mathrm{C}$ and the largest concentration value is $\mathrm{Fe}$. The content of $\mathrm{Fe}$ in this fly ash can be removed using physical, chemical, and incineration methods. The physical and chemical treatment process is intended to reduce or eliminate the nature or the power of poisons in hazardous and toxic waste materials. The process of treating hazardous and toxic waste utilizing incineration/burning at high temperatures can also reduce the content of hazardous and toxic materials. The activated fly ash material contains mineral quartz $\left(\mathrm{SiO}_{2}\right)$, which is an essential material in the adsorption process. Fly ash needs to be considered as the right material for the landfill containment system because of the properties it possesses. Table 2 shows the elements contained in the composite material.

\section{Permeability Test}

The permeability coefficient depends on the viscosity of the liquid, grain size distribution, pore number, grain surface roughness and degree of soil saturation. Other factors that affect the seepage properties of clay are the ion concentration and thickness of the water layer attached to the clay grains. The permeability test results show that the increasing content of bentonite in the mixture leads to the decrease of the permeability coefficient value obtained, with the amount of $1.653 \times 10^{-6} \mathrm{~cm} \cdot \mathrm{s}^{-1} ; 4.065 \times 10^{-7} \mathrm{~cm} . \mathrm{s}^{-1} ; 2.567$ $\mathrm{x} 10^{-7} \mathrm{~cm} \cdot \mathrm{s}^{-1}$, and $1.584 \times 10^{-7} \mathrm{~cm} . \mathrm{s}^{-1}$ respectively. These results also show that the value of the permeability coefficient depends on the size of the soil grain, where the smaller the grain size the lower the ability to pass water. The greatest permeability is obtained in pure fly ash samples where the value of the permeability coefficient $(\mathrm{k})$ is $1.653 \times 10^{-6} \mathrm{~cm} \cdot \mathrm{s}^{-1}$. In contrast, the lowest permeability was found in the fly ash samples mixed with $25 \%$ bentonite with the permeability coefficient (k) value of $1.584 \times 10^{-7} \mathrm{~cm} \cdot \mathrm{s}^{-1}$. Among the treatments that have been carried out, the use of fly ash material that is not mixed with bentonite does not meet local regulations where the permeability coefficient of the base layer of the landfill must be less than $10^{-6} \mathrm{~cm} \cdot \mathrm{s}^{-1}$. The result of this study is relevant to the study conducted by Amadi and Eberemu (2012) which stated that the addition of bentonite to the composite can reduce the permeability value to meet the permitted criteria (Amadi and Eberemu, 2012). The same permeability results were shown in a study conducted by Pandey and Jain (2017) which stated that the optimum value of the bentonite content in the FAB mixture was $20 \%$. Increasing the amount of bentonite causes a constant decrease in the permeability value of $9 \%$. However, when the content of bentonite has reached $20 \%$ of dry weight 
Table 3. Direct shear and permeability test results

\begin{tabular}{|c|c|c|c|c|c|c|c|}
\hline \multirow[t]{2}{*}{ No. } & \multirow[t]{2}{*}{ Treatment } & Normal Stress & $\begin{array}{c}\text { Shear stress } \\
(\sigma)\end{array}$ & $\begin{array}{c}\text { Cohesion } \\
\left(c^{\prime}\right)\end{array}$ & $\begin{array}{c}\text { Soil shear angle } \\
\left(\phi^{\prime}\right)\end{array}$ & $\begin{array}{c}\text { Soil shear stress } \\
(\mathrm{T})\end{array}$ & Permeability (k) \\
\hline & & $\mathrm{kN} \cdot \mathrm{m}^{-2}$ & $\mathrm{kN} \cdot \mathrm{m}^{-2}$ & $\mathrm{kN} \cdot \mathrm{m}^{-2}$ & $\circ$ & $\mathrm{kN} \cdot \mathrm{m}^{-2}$ & $\mathrm{~cm} \cdot \mathrm{s}^{-1}$ \\
\hline \multirow{3}{*}{1} & \multirow{3}{*}{$\mathrm{FAB}_{0}$} & 41.2 & 40.43 & \multirow{3}{*}{9.5} & \multirow{3}{*}{42} & 102.14 & \multirow{3}{*}{$1.653 \times 10^{-6}$} \\
\hline & & 57.5 & 51.09 & & & 126.57 & \\
\hline & & 73.7 & 64.43 & & & 157.13 & \\
\hline \multirow{3}{*}{2} & \multirow{3}{*}{$\mathrm{FAB}_{15}$} & 41.2 & 44.69 & \multirow{3}{*}{15.48} & \multirow{3}{*}{39} & 177.01 & \multirow{3}{*}{$4.065 \times 10^{-7}$} \\
\hline & & 57.5 & 51.83 & & & 202.82 & \\
\hline & & 73.7 & 66.67 & & & 256.46 & \\
\hline \multirow{3}{*}{3} & \multirow{3}{*}{$\mathrm{FAB}_{20}$} & 41.2 & 59.34 & \multirow{3}{*}{45.06} & \multirow{3}{*}{20} & 177.81 & \multirow{3}{*}{$2.567 \times 10^{-7}$} \\
\hline & & 57.5 & 63.26 & & & 186.58 & \\
\hline & & 73.7 & 70.18 & & & 202.06 & \\
\hline \multirow{3}{*}{4} & \multirow{3}{*}{$\mathrm{FAB}_{25}$} & 41.2 & 61.48 & \multirow{3}{*}{46.26} & \multirow{3}{*}{19} & 55.58 & \multirow{3}{*}{$1.584 \times 10^{-7}$} \\
\hline & & 57.5 & 64.82 & & & 56.09 & \\
\hline & & 73.7 & 72.85 & & & 57.30 & \\
\hline \multirow{3}{*}{5} & \multirow{3}{*}{$\mathrm{FAB}_{25 \mathrm{~s}}$} & 41.2 & 48.78 & \multirow{3}{*}{13.67} & \multirow{3}{*}{45} & 92.68 & \multirow{3}{*}{ - } \\
\hline & & 57.5 & 54.01 & & & 101.15 & \\
\hline & & 73.7 & 74.43 & & & 134.23 & \\
\hline
\end{tabular}

content, the decrease in permeability value is $7 \%$ (Pandey and Jain, 2017).

Compacted clay liner (CCL) is strongly influenced by the water content when pressure is applied, the compacting method, particle size, thickness and interlocking ability between layers (Roberts and Shimaoka, 2008; Ruiz et al., 2012). Clay is very susceptible to freezing and desiccation, so the application of mixed materials is very useful to improve the interlocking ability and prevent an increase in permeability coefficient (Herrmann et al., 2009). On the basis of the double layer theory, the decrease in the dielectric constant of the fluid in the pore will reduce the thickness of the double - layer, causing the clay particles to move closer between each other and cause shrinkage of the clay particles. If this condition continues to be left with a constant volume, the value of permeability (k) will increase due to the number of clay particles collapsing, the escape of water molecules from the clay particles, and the amount of liquid that passes through the clay particles ( $\mathrm{Li}$ et al., 2019). The water content and pressure applied are other critical factors that can influence hydraulic conductivity and affect the value of the permeability of the liner. When the amount of coarse aggregate (gravel) is greater than $2 / 3$ of the material mixture, the liner permeability tends to increase by more than $60 \%$. It is because the fine materials do not cover enough of the pores/voids between the coarse particles. It should be understood that the intended fine particle is not an expansive clay type. The liners that are permitted as containment systems must contain coarse particles in the composite below $30 \%$ of the total dry weight (Roberts and Shimaoka, 2008).

\section{Soil Shear Strength and Stability Analysis}

As mentioned by Ruiz et al. (2012), one of the critical factors in the selection of the materials for landfill containment systems is the strength of the material in holding loads, both vertically and horizontally (Ruiz et al., 2012). The direct shear test is used to determine the stability of the material used on the leachate-retaining soils that are found on the slope of the landfill (Lin et al., 2018; Slim et al., 2016). Table 3 shows that the results of direct shear test from $\mathrm{FAB}_{0}, \mathrm{FAB}_{15}, \mathrm{FAB}_{20}, \mathrm{FAB}_{25}$, and $\mathrm{FAB}_{25 \mathrm{c}}$ at normal stresses are $41.2 \mathrm{kN} / \mathrm{m}^{2}$, $57.5 \mathrm{kN} / \mathrm{m}^{2}$, and $73.7 \mathrm{kN} / \mathrm{m}^{2}$ respectively, which increase in value. Meanwhile, the shear angles of $\mathrm{FAB}_{15}, \mathrm{FAB}_{20}$, and $\mathrm{FAB}_{25}$ decreased with the addition of bentonite. The shear stress increases due to the formation of a pozzolanic reaction, which is the reaction between calcium in the fly ash with aluminum and silicate in the soil, producing a hard and stiff mass (Sivapullaiah and Baig, 2011).

The addition of bentonite to the fly ash seemed to be able to improve the engineering properties of the mixture material. The addition of bentonite can reduce the angle of shear until it is below 30 degrees, which means it is safe from collapse potential (Slim et al., 2016). Shear strength in CCL is very dependent on the normal stress applied. At low normal stress, internal friction angle will 


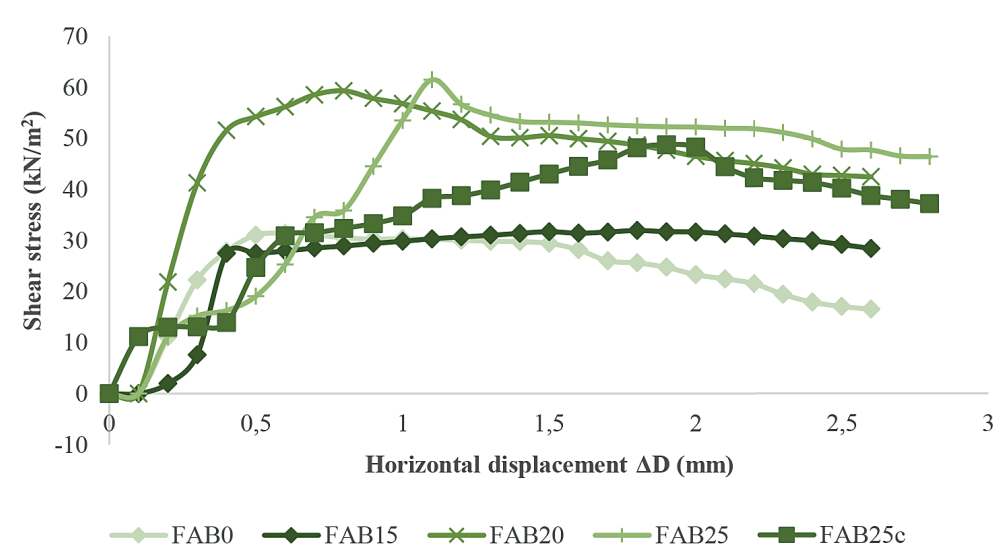

(a)

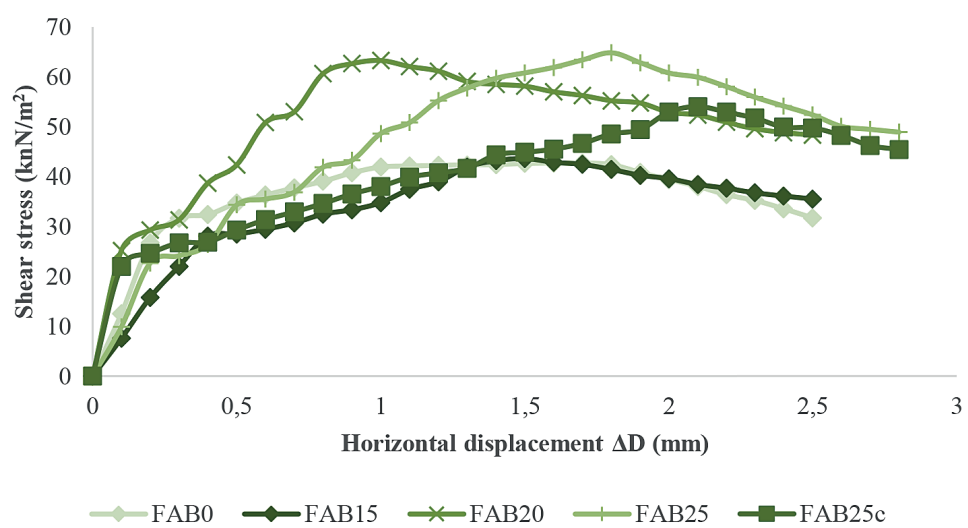

(b)

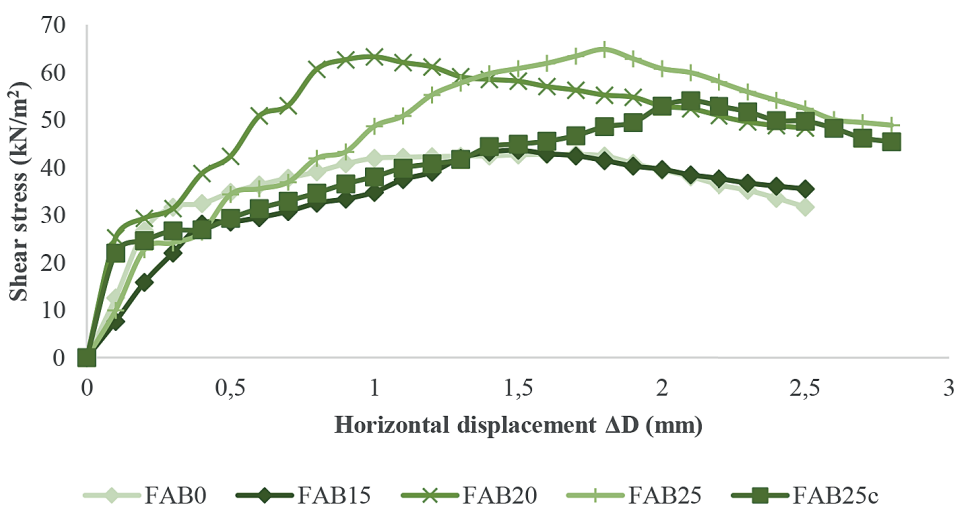

(c)

Figure 3. Relationship between shear stress with horizontal displacement in normal stress (a) $41.2 \mathrm{kN} \cdot \mathrm{m}^{-2}$, (b) $57.5 \mathrm{kN} \cdot \mathrm{m}^{-2}$, and (c) $73.7 \mathrm{kN} \cdot \mathrm{m}^{-}$

rise in the beginning and start to drop along with the increase of normal stress value (Bergado et al., 2006). The moisture content is also known to have an impact on the value of shear resistance. Increasing the water content will reduce the shear resistance of liner material (Lin et al., 2018). Bentonite is a material that is able to maintain the hydraulic performance of a liner. Nevertheless, the internal shear of bentonite will shrink after the liner layer is saturated, causing instability of the liner layer which is placed at an extreme slope (Budihardjo et al., 2012).

Figure 3 illustrates the results of the shear stress - shear displacement relationship at each normal pressure given. In the picture, it can be seen that the shear strength of each composite has a different behavior but tends to have the same trend in each loading. An interesting condition is seen in the mixture which is cured using $\mathrm{NH}_{4} \mathrm{Cl}$ $\left(\mathrm{FAB}_{25 \mathrm{c}}\right)$. At normal pressure of $41.2 \mathrm{kN} \cdot \mathrm{m}^{-2}$, the 
peak shear strength of $\mathrm{FAB}_{25 \mathrm{c}}$ occurred at $\pm 2 \mathrm{~mm}$ displacement and remained constant for greater displacement. In addition, this displacement pattern tends to be stable at other normal levels of stress. Different conditions are shown in the use of other types of treatment using distilled water where shear displacement changes to reach peak shear strength. For example, when $\mathrm{FAB}_{15}$ was given a normal stress of $41.2 \mathrm{kN} \cdot \mathrm{m}^{-2}$, it reached its peak shear strength at $<0.5 \mathrm{~mm}$ displacement, while normal stress of 57.5 and 73.7 reached peak shear strength at, which then experienced a significant post-peak loss. The greatest peak shear strength was achieved by $\mathrm{FAB}_{25}$ and $\mathrm{FAB}_{20}$ with a value of $\pm 60 \mathrm{kN} . \mathrm{m}^{-2}$. This explains that the addition of bentonite affects the shear strength of each mixture. The failure that occurs in all composite materials is contrary to the research conducted by Eid (2011), which reported than only $20 \%$ shear strength loss occurred soil/GCL interfaces with normal stress of $75 \mathrm{kN} \cdot \mathrm{m}^{-2}$. This difference occurs because of the high value of plasticity index mixtures held by various composites in this study. In the same study, GCL with normal stress of $300 \mathrm{kN} \cdot \mathrm{m}^{-2}$ had a peak shear stress value of $120 \mathrm{kN} \cdot \mathrm{m}^{-2}$. An increase in peak shear stress is still needed for the fly ash-bentonite mixture to obtain a material that is more stable and safer from collapse (Eid, 2011).

The addition of bentonite tends to increase the safety factors that appear in Geoslope/W modeling. On the addition of $0 \%, 15 \%, 20 \%$, and $25 \%$ bentonite, the values of safety factors are 1,$660 ; 1,662 ; 1,668 ; 1,674$ and 1,668. These conditions indicate that the addition of bentonite will increase the bonds between particles, bearing capacity, and shear strength of the material. The largest safety factor was obtained by $\mathrm{FAB}_{25}$ which was curing using distilled water with a value of 1,674 which met the standard for short-term safety factor in slope. The mixtures that were hydrated using salt are known to have greater hydraulic conductivity compared to the mixtures that were permeated with non-alkaline solutions. Immersion using saline solution will cause an increase in hydraulic conductivity three times higher than the previous value (Budihardjo, 2016). The addition of salt concentration will reduce the compression index, which occurs because of the decrease in the thickness of the double layer diffuse due to the salt being introduced in the pore fluid so that the maximum dry density increases. In addition, the addition of cation valence will also increase hydraulic conductivity and reduce swelling volume. The presence of salt solutions and cations in the pore fluid will create a gradient of free energy, which will make the water left the interlayer area. Salt solutions will reduce the liquid limit of composite materials used as leachate retaining liners (Shariatmadari et al., 2011). This research is limited to static load, which cannot reflect the dynamic factors that affect the stability of the containment system.

\section{CONCLUSIONS}

Addition of bentonite to the reactor: $0 \%$ $\left(\mathrm{FAB}_{0}\right), 15 \%\left(\mathrm{FAB}_{15}\right), 20 \%\left(\mathrm{FAB}_{20}\right)$ and $25 \%$ $\left(\mathrm{FAB}_{25}\right)$ can increase the value of plasticity index and optimum moisture content. The results showed that the mixture of fly ash and $25 \%$ bentonite $\left(\mathrm{FAB}_{25}\right)$ had the smallest permeability and met the standard parameters for compacted clay liners with hydraulic conductivity (k) values reaching $1.584 \times 10^{-7} \mathrm{~cm} / \mathrm{s}$. Bentonite, which is used as a mixing material from fly ash, can minimize the potential of collapse to occur. The largest safety factor was 1.674 in $\mathrm{FAB}_{25}$, which met the safety factor standard for the installation of shortterm liner slopes (in the edge of construction). Fly ash used as a landfill linter with the addition of other materials such as bentonite has been proven to reduce the permeability coefficient of mixed soils. The use of other waste materials as basic landfill coatings still can be explored further.

\section{Acknowledgments}

This research was funded by Direktorat Riset dan Pengabdian Masyarakat, Direktorat Jenderal Penguatan Riset dan Pengembangan, Kementerian Riset, Teknologi dan Pendidikan Tinggi Tahun Anggaran 2020, Number 257-69/UN7.6.1/ $\mathrm{PP} / 2020$.

\section{REFERENCES}

1. Alla V, Sasmal S K, Behera R N, Patra C. Development of Alternate Liner Material by Blending Fly Ash, Local Soil and Bentonite. Indian Geotechnical Conference; 2017 GeoNEst; India; 2017

2. Amadi A A, Eberemu A O. Delineation of compaction criteria for acceptable hydraulic conductivity of lateritic soil-bentonite mixtures designed as landfill liners. Environmental Earth Science, 67, 999-1006. 
3. Benson $\mathrm{C} \mathrm{H}$, Zhai H, Wang X. Estimating hydraulic conductivity of compacted clay liners. Journal of Geotechnical Engineering; 1994: 120, 366-387.

4. Bergado D T, Ramana G V, Sia H I, Varun. Evaluation of interface shear strength of composite liner system and stability analysis for a landfill lining system in Thailand. Geotextiles and Geomembranes; 2006: 24, 371-393.

5. Budihardjo M A. The Influence of Salt Solution on Morphological Changes in a Geosynthetic Clay Liner. Advances in Materials Science and Engineering; 2016.

6. Budihardjo M A, Chegenizadeh A, Nikraz H. A Review of Key Factors on Geosynthetic Clay Liners ' Performance as Liner System. International Journal of Biological, Ecological and Environmental Science. 2012: 1, 117-119.

7. Cokca E, Yilmaz Z. Use of rubber and bentonite added fly ash as a liner material. Waste Management; 2004: 24, 153-164.

8. Çoruh S, Ergun O N. Use of fly ash, phosphogypsum and red mud as a liner material for the disposal of hazardous zinc leach residue waste. Journal of Hazardous Material; 2010: 173, 468-473.

9. Ehrlich M, Almeida S, Curcio D. Hydro-mechanical behavior of a lateritic fiber-soil composite as a waste containment liner. Geotextiles and Geomembranes; 2019: 47, 42-47.

10. Eid, H T. Shear strength of geosynthetic composite systems for design of landfill liner and cover slopes. Geotextiles and Geomembranes; 2011: 29, 335-344.

11. Ganjian E, Claisse P, Tyrer M., Atkinson A. Preliminary investigations into the use of secondary waste minerals as a novel cementitious landfill liner. Construction Building Materials; 2004: 18, 689-699.

12. Herrmann I, Svensson M, Ecke H, Kumpiene J, Maurice C, Andreas L, Lagerkvist A. Hydraulic conductivity of fly ash-sewage sludge mixes for use in landfill cover liners. Water Research; 2009: 43, 3541-3547.

13. Kalkan E. Utilization of red mud as a stabilization material for the preparation of clay liners. Engineering Geology; 2006: 87, 220-229.

14. Li L Y, Zhang H, Gorgy T, Grace J R, Effect of polybrominated diphenyl ethers on sand-bentonite liner material. Waste Management; 2019: 89, 73-82.

15. Lin H, Zhang L, Xiong Y. Research on shear strength of needle-punched GCL by simple-shear of composite liner. Engineering Geology; 2018: 244, 86-95.

16. Mishra A K, Ravindra V. On the Utilization of Fly Ash and Cement Mixtures as a Landfill Liner Material. International Journal of Geosynthetics and Ground Engineering; 2015: 1.
17. Mukherjee K, Mishra A K. Influence of tyre chips on the behaviour of sand-bentonite mixture, in: Indian Geotechnical Conference 2017 GeoNEst. pp. 14-17.

18. Mukri M, Zainuddni A N, Abdullah N A, Ibrahim N. Performance of different percentage on nano-kaolin as additives in soil liner application. Materials Today Proceeding; 2018: 5, 21604-21611.

19. Pandey M, Jain P R. Compaction and seepage characteristics of Fly ash mixed with. nternational Research Journal of Engineering and Technology; 2017: 4, 2277-2280.

20. Roberts A A, Shimaoka T. Analytical study on the suitability of using bentonite coated gravel as a landfill liner material. Waste Management; 2008: 28, 2635-2644.

21. Rout S, Singh S P. 2017. Effects of Molding Moisture Content on Strength and Hydraulic Properties of Pond ash-Bentonite Mixes, in: Indian Geotechnical Conference 2017 GeoNEst. pp. 14-17.

22. Ruiz, A I, Fernández R, Sánchez Jiménez N, Rodríguez Rastrero M, Regadío M, de Soto I S, Cuevas $\mathrm{J}$. Improvement of attenuation functions of a clayey sandstone for landfill leachate containment by bentonite addition. Science of Total Environment; 2012 : 419, 81-89.

23. Shariatmadari N, Salami M, Fard M K, Effect of inorganic salt solutions on some geotechnical properties of soil-bentonite mixtures as barriers. International Journal of Civil Engineering; 2011: 9, 103-110.

24. Sivapullaiah P V, Baig M A A, Gypsum treated fly ash as a liner for waste disposal facilities. Waste Management; 2011: 31, 359-369.

25. Slim G I, Morales M, Alrumaidhin L, Bridgman P, Gloor J, Hoff S T, Odem W I. Optimization of Polymer-Amended Fly Ash and Paper Pulp Millings Mixture for Alternative Landfill Liner. Procedia Engineering; 2016: 145, 312-318.

26. Turan N G, Ergun O N, Removal of $\mathrm{Cu}(\mathrm{II})$ from leachate using natural zeolite as a landfill liner material. Journal of Hazardous Material; 2009: 167, 696-700.

27. Vimonses V, Lei S, Jin B, Chow C W K, Saint C. Kinetic study and equilibrium isotherm analysis of Congo Red adsorption by clay materials. Chemical Engineering Journal; 2009: 148, 354-364.

28. Wu H, Wen Q, Hu L, Gong M, Tang Z. Feasibility study on the application of coal gangue as landfill liner material. Waste Management; 2017: 63, 161-171.

29. Xu S, Bian M, Li C, Wu X, Wang Z. Effects of calcium concentration and differential settlement on permeability characteristics of bentonite-sand mixtures. Applied Clay Science; 2018: 153, 16-22. 